\title{
Letter to the Editor: Critical Distance in Churches: Comments on Carvalho \& Lencastre (2000)
}

\author{
Pedram Jafari Shalkouhi \\ Department of Environmental Engineering, Graduate School of the Environment and Energy, Science and Research \\ Branch, Islamic Azad University, 1477893855, Tehran, Iran
}

(Received 31 January 2011, accepted 28 February 2011)

The goal of this letter is to comment on the article "Catholic Churches, Sound Reinforcement Systems and RASTI" by Carvalho \& Lencastre (2000). Carvalho \& Lencastre could have calculated or measured critical distance in each church to know the reason of decreasing RASTI in the direct field. It is concluded that in spaces with long reverberation time, the number and position of loudspeakers with regard to critical distance must be taken into consideration.

\section{NOMENCLATURE}

RASTI - Rapid Speech Transmission Index

SRS — Sound Reinforcement Systems

\section{INTRODUCTION}

Critical distance is defined as the distance away from the sound source where the direct sound field of the source and the reverberant field of the room are equal. In addition, critical distance is affected by the directivity of the sound source and the amount of absorptions in a room. ${ }^{1}$ Critical distance can be computed as follows:

$$
D_{C}=0.14 \sqrt{Q R} \quad \text { (meters or feet) }
$$

where $Q$ is the directivity factor of the sound source, and $R$ is the room constant in the enclosed space. The room constant is:

$$
R=\frac{S \bar{\infty}}{1-\bar{\infty}} \quad \text { (square meters or square feet) }
$$

where $S$ is the surface area in the space, and $\bar{\infty}$ is the average absorption coefficient in the space. ${ }^{2}$

Critical distance is important with regard to concepts including intelligibility. ${ }^{3}$ Beyond the critical distance, ability of recognition remains essentially constant. ${ }^{4}$

\section{DISCUSSION}

Carvalho \& Lencastre measured RASTI in 31 hard-surfaced unoccupied churches with and without the SRS. ${ }^{5}$ They selected 4 different positions in each church from the altar area. They concluded that only for distances greater than about $11 \mathrm{~m}$ from the altar, RASTI was improved with the SRS on.

Carvalho \& Lencastre could have calculated or measured the critical distance in each church to know the reason of decreasing RASTI in the direct field, or up to about $11 \mathrm{~m}$ according to Figs. 7 and 8 of Carvalho \& Lencastre's results. ${ }^{5}$ Hence, the reason may be due to the existence of additional loudspeakers in the direct field which cause more sound energy reflections, or the reason may be due to the existence of additional loudspeakers in the reverberant field that cause sound energy to reflect toward the direct field. In addition, it seems that the SRS improved RASTI in all churches in the direct field because for each loudspeaker, a direct field and a reverberant field can be supposed in the reverberant field or the distance greater than $11 \mathrm{~m}$, according to Fig. 1 of Carvalho \& Lencastre's results. ${ }^{5}$ However, $11 \mathrm{~m}$ is not real critical distance in all churches according to the critical distance equation and Eq. (1) of Carvalho \& Lencastre's results. ${ }^{5}$

\section{CONCLUSIONS}

For large spaces like a church with long reverberation time, considering enough loudspeakers for the direct field may lead to acceptable RASTI when SRS are on. Also, in the reverberant field, amplification systems may be effective to improve RASTI when they are enough too. Moreover, the loudspeakers' position with regard to critical distance must be taken into consideration.

Nevertheless, it is difficult to achieve acceptable speech intelligibility in spaces with long reverberation time.

\section{REFERENCES}

1 Eargle, J. Handbook of Recording Engineering, SpringerVerlag, New York, (2002), 4th ed.

2 Eargle, J. The Microphone Book, Focal Press, Great Britain, (2001), 1st ed.

3 Ballou, G. Handbook for Sound Engineers, Focal Press, Great Britain, (2005), 3rd ed.

4 Valente, M., Hosford-Dunn, H., and Roeser, R. J. Audiology Treatment, Thieme, (2007), 2nd ed.

5 Carvalho, A. P. O. and Lencastre, M. M. F. Catholic churches, sound reinforcement systems and RASTI, International Journal of Acoustics and Vibration, 5(1), 7-14, (2000). 